\title{
The Recovery of Indium Metal from ITO-scrap using Hydrothermal Reaction in Alkaline Solution
}

\author{
Jung-Chul Park \\ Department of Engineering in Energy \& Applied Chemistry, Center for Green Fusion Technology, \\ Silla University, Busan 617-736, Korea. E-mail: parkjc@silla.ac.kr \\ Received June 13, 2011, Accepted August 19, 2011
}

Key Words : Recovery, Indium, ITO-scrap, Hydrothermal reaction, Alkaline solution

Indium element is very rare one and tend to occur at low concentrations in sulfide minerals rather than as oxides. Indium $(0.21 \mathrm{ppm})$ is similar in abundance to $\mathrm{Sb}$ and $\mathrm{Cd}$, whereas $\mathrm{Tl}(0.7 \mathrm{ppm})$ is close to Tm and somewhat less abundant than $\mathrm{Mo}, \mathrm{W}$, and $\mathrm{Tb}(1.2 \mathrm{ppm})$. Indium, like $\mathrm{Ga}$, is normally recovered by electrolysis after prior concentration in processes leading primarily to other elements $(\mathrm{Pb} / \mathrm{Zn})$. Indium metal is soft, silvery one with a brilliant lustre, and used to protect bearings against wear and corrosion. Indium metal frequently uses in low-melting alloys and in electronic devices as its low melting-point $\left(\approx 156^{\circ} \mathrm{C}\right) .{ }^{1}$

Indium demand is expected to increase throughout the next decade, especially by dint of growth for liquid crystal displays, solar energy cell, high-definition television, semiconductor materials, batteries, low-temperature solders, and electronic application. Indium is used in various forms such as indium oxide/indium-tin oxide, indium metal and alloy, and indium compounds. ${ }^{2,3}$

Particularly, indium-tin oxide (ITO) formed by doping indium oxide with approximately $10 \%$ of tin oxide, increases electrical conductivity without significantly affecting transparency of glass. Flat panel display applications for indium in the form of ITO are the most important end uses, more than one-half of the world's indium consumption.

ITO films on glass substrate are generally fabricated by DC magnetron sputtering using ITO ceramic target. Unfortunately, the used ITO targets (residual weight percent 60$70 \%$ ) should be replaced because of race track formation. ${ }^{4-6}$ So, it might be said that the recycling of unused ITO target is indispensable as indium is a trace element and very high price in LME (London Metal Exchange).

It is well known that in commercial process of indium recovery, ITO scrap is leached first using strong acids such as $\mathrm{HNO}_{3}$ (or $\mathrm{HCl}$, and $\mathrm{H}_{2} \mathrm{SO}_{4}$ ). As shown in $\mathrm{In}_{1.82} \mathrm{Sn}_{0.18} \mathrm{O}_{3}$ obtained by doping indium oxide with approximately $10 \%$ of tin oxide, tin is the major impurity in recovery process of indium metal from ITO target-scrap. As tin is chemically very similar to indium, the recovery of pure indium metal from ITO scrap is a knotty problem. In addition to unused ITO target, various impurity metals including Al, Mo, Fe, $\mathrm{Ni}$, and $\mathrm{Cr}$ and so on, are contaminated in the collection process of ITO scrap.

Many researchers have designed the various methods to recover the pure indium metal from ITO scrap. Indium has been recovered from residue of acetate leaching by chemical replacement with zinc in 5-20\% $\mathrm{HCl}^{7}$ Maslii et al. have designed the electrolytic method to recover indium from concentrated sulfate solutions. ${ }^{8}$ Barakat recovered indium from alloy wire scrap containing lead, tin, and indium metals. ${ }^{9}$

The newly developed method to remove tin and purify indium metal from ITO target scrap has been reported using molten $\mathrm{NaOH}^{10}$ and ozonization. ${ }^{11}$ Among various technologies available today in advanced materials processing, the hydrothermal technique occupies a unique place owing to its advantages over conventional technologies. It covers processes like hydrothermal synthesis, hydrothermal transformation, hydrothermal decomposition, hydrothermal extraction, hydrothermal recycling, hydrothermal leaching, and so on. ${ }^{12}$ The previous report dealt with the removal of tin from ITO scrap, where the molten $\mathrm{NaOH}$ breaks chemical bonds of $\mathrm{In}_{2-\mathrm{x}} \mathrm{Sn}_{\mathrm{x}} \mathrm{O}_{3}$ compound, which results in the formation of $\mathrm{Na}_{2} \mathrm{SnO}_{3}$ and corresponding indium hydroxides. $\mathrm{As} \mathrm{Na}_{2} \mathrm{SnO}_{3}$ is soluble in water and easily removed in a washing step, the high purity of $\operatorname{In}(\mathrm{OH})_{3}$ can be easily recovered. ${ }^{10}$

Based on the previous results, it might be assured that the hydrothermal reaction in alkaline solution is a good solution to remove tin from ITO scrap. More especially, as the hydrothermal reaction in alkaline solution decomposes directly $\mathrm{In}_{2-\mathrm{x}} \mathrm{Sn}_{\mathrm{x}} \mathrm{O}_{3}$ compound into $\mathrm{In}(\mathrm{OH})_{3}$ and $\mathrm{Na}_{2} \mathrm{SnO}_{3}$ without using strong acids, it might abbreviate the commercial process of indium recovery.

In this paper, I demonstrate a new method to remove tin and purify indium metal from ITO target scrap using hydrothermal reaction in alkaline solution.

\section{Experimental Section}

ITO target-scrap was obtained from Samsung Corning Co., Ltd. The sample was crushed and pulverized. A $200 \mathrm{~g}$ of powder sample was mixed with $1 \mathrm{~L}$ distilled water and $2 \mathrm{~L}$ of $50 \% \mathrm{NaOH}$ solution in a round-shaped sus 316 container, and then heated on hot plate with stirrer for $5 \mathrm{~h}$. The $\mathrm{NaOH}$-treated powder was washed with distilled water until $\mathrm{pH} 7$ of residual solution, then filtered and dried at $150{ }^{\circ} \mathrm{C}$ in a dry-oven. The resulting powder was leached in 
$3 \mathrm{M} \mathrm{H}_{2} \mathrm{SO}_{4}$ solution at $80{ }^{\circ} \mathrm{C}$ for $1.5 \mathrm{~h}$. The indium sponge was obtained by cementation in sulfuric acid solution with aluminum plate $\left(\mathrm{pH} 2,60{ }^{\circ} \mathrm{C}\right)$, and then smelted at $450{ }^{\circ} \mathrm{C}$ in excess $\mathrm{NaOH}$.

$\mathrm{X}$-ray diffraction pattern of the sample was achieved by Schmadzu 6000 model with $\mathrm{Cu}-\mathrm{K}_{\alpha}$ radiation. The elemental analysis was performed by inductively coupled plasmaemission spectroscopy (ICP) with Labtam 8400 model.

\section{Results and Discussion}

In first step of most process of indium recovery from ITO scrap, the strong acid-leaching step has been adopted. However, in this work, the hydrothermal reaction was used in first step without using strong acids. Hydrothermal reaction of ITO scrap was performed on the home-made hydrothermal reactor as depicted in Figure 1. Hydrothermal conditions were as follows: temperature: $140{ }^{\circ} \mathrm{C}$, pressure: $0.51 \mathrm{~kg} / \mathrm{cm}^{2}$, reaction time: $5 \mathrm{~h}$.

After hydrothermal reaction, the powder of ITO scrap was washed and dried. Figure 2 reveals XRD patterns before and after hydrothermal reaction. XRD pattern-b) corresponds to ITO scrap as received, which is assigned as $\operatorname{In}_{2} \mathrm{O}_{3}$. As shown in Figure 2, The XRD pattern b) reveals that ITO target forms a single phase of $\operatorname{In}_{2} \mathrm{O}_{3}$ with cubic symmetry within a doping range of approximately $10 \%$ of tin oxide. After hydrothermal treatment, $\mathrm{In}_{2} \mathrm{O}_{3}$ phase is dramatically changed into $\mathrm{In}(\mathrm{OH})_{3}$ phase (pattern d) after washing with distilled

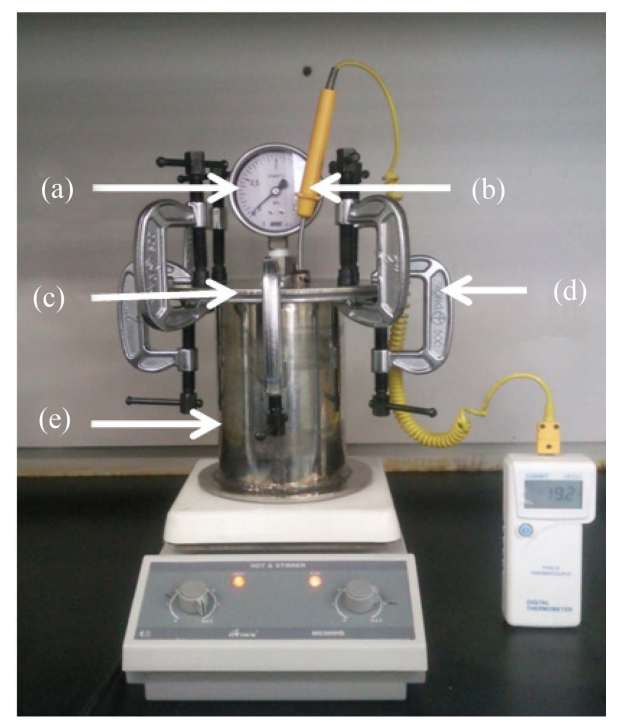

Figure 1. Home-made hydrothermal reactor: (a) pressure gauge; (b)digital thermometer; (c) silicone rubber; (d) clamp; (e) reaction vessel.

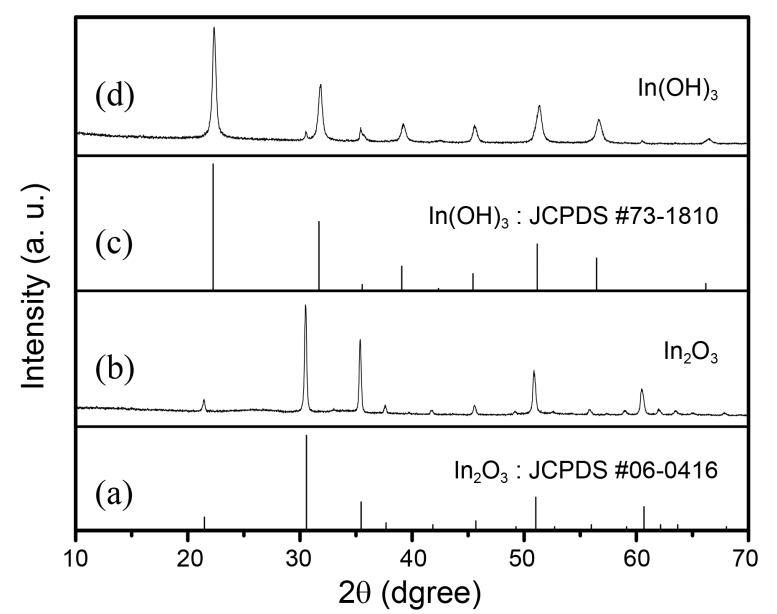

Figure 2. XRD patterns of ITO scrap powders: (a) $\operatorname{In}_{2} \mathrm{O}_{3}$ (jcpds \#06-0416); (b) before hydrothermal rxn; (c) $\operatorname{In}(\mathrm{OH})_{3}$ (jcpds \#731810); (d) after hydrothermal reaction for (b) sample.

water. It is probably due to the formation of $\operatorname{In}(\mathrm{OH})_{3}$ and $\mathrm{Na}_{2} \mathrm{SnO}_{3}$ under hydrothermal treatment. As $\mathrm{SnO}_{3}{ }^{2-}$ can be easily removed in washing step, the highly purified $\mathrm{In}(\mathrm{OH})_{3}$ is obtained ${ }^{13}$ as indicated in pattern d). It should be pointed out that $\mathrm{NaOH}$ under hydrothermal conditions breaks chemical bonds of $\mathrm{In}_{2-\mathrm{x}} \mathrm{Sn}_{\mathrm{x}} \mathrm{O}_{3}$ compound, which results in the formation of $\mathrm{Na}_{2} \mathrm{SnO}_{3}$ and corresponding indium hydroxides, which is well coincident with Pourbaix' E-pH diagram indicating that $\mathrm{Sn}(\mathrm{OH})_{2}$ and $\mathrm{Sn}(\mathrm{OH})_{4}$ transform into $\mathrm{HSnO}_{2}{ }^{-}$or $\mathrm{SnO}_{3}{ }^{2-}$ in an alkaline solution. ${ }^{14}$ The resulting $\mathrm{In}(\mathrm{OH})_{3}$ powder was dissolved using $3 \mathrm{M} \mathrm{H}_{2} \mathrm{SO}_{4}$ solution. Indium was recovered as sponge metal through cementation with aluminum plate on the basis of standard reduction potentials $\left(\mathrm{E}^{\mathrm{o}}\right.$ for $\left.\mathrm{In}^{3+} / \mathrm{In}=-0.338 \mathrm{~V}, \mathrm{Al}^{3+} / \mathrm{Al}=-1.680 \mathrm{~V}\right)$ in $\mathrm{H}_{2} \mathrm{SO}_{4}$ solution with $\mathrm{pH}$ value of 2 at $60{ }^{\circ} \mathrm{C}$. Indium sponge metal is smelted at $450{ }^{\circ} \mathrm{C}$ by excess $\mathrm{NaOH}$ which is used for preventing indium from oxidation and absorbing metal impurities. Table 1 represents the ICP-elemental analysis for ITO scrap as received and the finally recovered indium

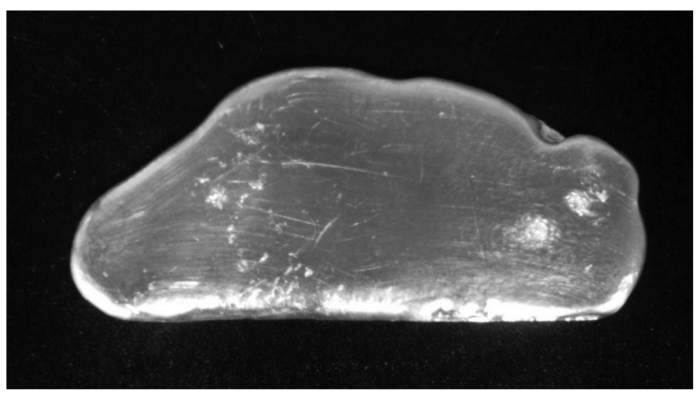

Figure 3. The finally recovered indium metal ingot.

Table 1. ITO scrap and finally recovered Indium metal: ICP analysis ${ }^{a}$

\begin{tabular}{|c|c|c|c|c|c|c|c|}
\hline & $\begin{array}{c}\text { In } \\
(\%)\end{array}$ & $\begin{array}{l}\mathrm{Sn} \\
(\%)\end{array}$ & $\begin{array}{c}\mathrm{Al} \\
(\%)\end{array}$ & $\begin{array}{l}\text { Mo } \\
(\%)\end{array}$ & $\begin{array}{c}\mathrm{Cu} \\
(\%)\end{array}$ & $\begin{array}{l}\mathrm{Ni} \\
(\%)\end{array}$ & $\begin{array}{l}\mathrm{Co} \\
(\%)\end{array}$ \\
\hline ITO scrap as received & 47.08 & 16.30 & 0.889 & 0.187 & 0.236 & 0.002 & 0.001 \\
\hline
\end{tabular}

${ }^{a}$ The samples are dissolved in aqua regia solution. 
ingot. ICP analysis reveals that the indium purity of ITO scrap is approximately $47.08 \%$. The purity of recovered indium ingot is found to be $99.95 \%$ without any further purification step except hydrothermal treatment.

Based on the XRD and ICP results, the advantages of hydrothermal reaction can be described as follows:

i) bond dissociation of $\mathrm{In}_{2-\mathrm{x}} \mathrm{Sn}_{\mathrm{x}} \mathrm{O}_{3}$ phase in alkaline solution at elevated temperature and vapor pressure

ii) the formation of water soluble $\mathrm{Na}_{2} \mathrm{SnO}_{3}$ and water insoluble $\mathrm{In}(\mathrm{OH})_{3}$ phase in alkaline solution

iii) the effect of impurity removal due to the dissolution of fine precipitate, $\operatorname{In}(\mathrm{OH})_{3}$ under the diluted acid solution

iv) the effect of simplification of indium recovery process due to the abbreviation of acid-leaching step

The newly developed hydrothermal reaction to recover indium metal from ITO scrap may become a promising technique for recycling fields of rare metals.

Acknowledgments. This work (Grants No. 2010-05-004) was supported by Business for Cooperative R\&D between Industry, Academy, and Research Institute funded Korea Small and Medium Business Administration in 2010.

\section{References}

1. Greenwood, N. N.; Earnshaw, A. Chemistry of the Elements; Pergamon Press: Oxford, New York, 1984; pp 245-247.

2. Ulrich, S. S.; Peter, M. H. Indium; Springer: Heidelberg, 2002; pp 167-169.

3. Alfantazi, A. M.; Moskalyk, R. R. Minerals Engineering 2003, $16,687$.

4. Guillen, C.; Herrero, J. Thin Solid Films 2006, 510, 260.

5. Yang, C. H.; Lee, S. C.; Chen, S. C.; Lin, T. C. Materials Science and Engineering $B$ 2006, 129, 154.

6. Hu, Y.; Dia, X.; Wang, C.; Wang, T. Vacuum. 2004, 75, 183

7. Adamski, Z.; Krolicki, F.; Rumianowski, S.; Wojciechowski, W. Pol. Patent. 1985, PL 129, 966.

8. Maslii, A. I.; Belobaba, A. G.; Vais, A. A. Russian Journal of Applied Chemistry 1999, 72, 1165.

9. Barakat, M. A. Hydrometallurgy 1998, 49, 63.

10. Park, J. C. Bull. Korean Chem. Soc. 2008, 29, 255.

11. Park, J. C. Bull. Korean Chem. Soc. 2009, 30, 3141.

12. Byrappa, K., Adschiri, T. Progress in Crystal Growth and Characterization of Materials 2007, 53, 117.

13. Chu, X. Materials Science and Engineering B 2004, 106, 305.

14. Pourbaix, M. Atlas D'Équilibres Lectrochimiques; Paris, 1963. 